The Balance Gap 
This page intentionally left blank 


\section{The Balance Gap}

Working Mothers and the Limits of the Law

\section{Sarah Cote Hampson}

Stanford Law Books

An Imprint of Stanford University Press

Stanford, California 
Stanford University Press

Stanford, California

(C) 2017 by the Board of Trustees of the Leland Stanford Junior University. All rights reserved.

No part of this book may be reproduced or transmitted in any form or by any means, electronic or mechanical, including photocopying and recording, or in any information storage or retrieval system without the prior written permission of Stanford University Press.

Printed in the United States of America on acid-free, archival-quality paper

Library of Congress Cataloging-in-Publication Data

Names: Hampson, Sarah Cote, author.

Title: The balance gap : working mothers and the limits of the law / Sarah Cote Hampson.

Description: Stanford, California : Stanford Law Books, an imprint of Stanford University Press, 2017. | Includes bibliographical references and index.

Identifiers: LCCN 201603752I (print) | LCCN 2016038326 (ebook) | ISBN 9781503600058 (cloth : alk. paper) | ISBN 978150360215I (pbk. : alk. paper) | ISBN 9781503602175

Subjects: LCSH: Mothers-Employment-Law and legislationUnited States. | Working mothers_-Legal status, laws, etc.United States. | Work and family-United States. | Women college teachers_-Legal status, laws, etc.—United States. | United StatesArmed Forces-Women-Legal status, laws, etc.

Classification: LCC KF3555 .H36 2017 (print) | LCC KF3555 (ebook) | DDC 344.7301/44- dc23

LC record available at https://lccn.loc.gov/201603752I 
For Chris, Anna, and Elisabeth 
This page intentionally left blank 